\section{WORD WATCH}

\section{Black hole}

A county commissioner in Dallas who compared the local trafficticket collection office to a "black hole", was told by a judge last week to apologize for his "racist remark". He had to explain that it was a scientific term.

\section{SCORECARD}

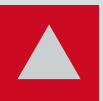

Sausage dogs

A survey of 6,000 dog owners and 33 breeds

found the dachshund to be most aggressive. Their nastiness may have gone unnoticed because of their diminutive size, the researchers say.

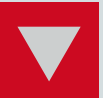

\section{Dog sausage}

China has ordered dog meat to be taken off the menu at its official Olympic restaurants, to avoid offending foreign visitors.

\section{SHOWBIZ NEWS}

\section{Lab rats}

Following in the steps of US TV's The Big Bang Theory, comes a new British sitcom Lab Rats, which revolves around a fictional lab at St Dunstan's University and the comic incompetence of its staff (led by a drunken professor living off the reputation of his ageing Nobel prize). Though dubbed a "new formula" for comedy, sadly the reviews have largely called this TV experiment a failure.

\section{ZOO NEWS}

\section{Bear suit}

The legal owner of Knut, the now-famous polar bear that was rejected by his mother and raised by keepers at Berlin Zoo, is going to court. The Tierpark Neumünster says it wants a share of Berlin Zoo's increased profits, and has vaguely threatened to remove Knut from Berlin if it doesn't get its way.

Sources: Dallas Morning News, Appl. Anim. Behav. Sci., Xinhua, BBC, Blomberg

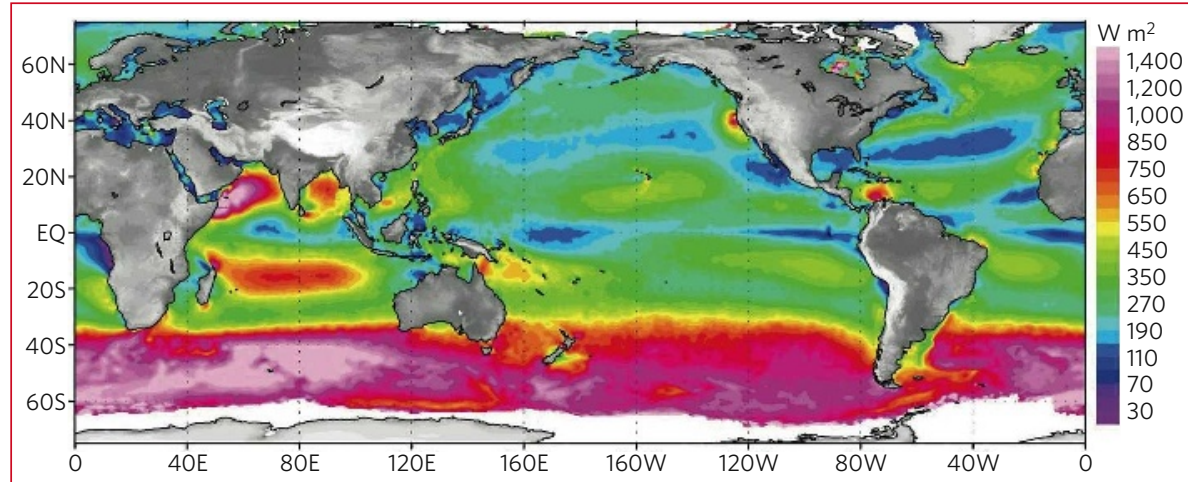

SNAPSHOT \section{Global wind power}

This map of the average power of the world's winds is derived from 8 years of data from a space-based radar called a scatterometer. The radar measures the scatter in microwaves bouncing off the sea into orbit; the wave motion measured indicates wind speed. The image shows windpower density in December, January and February; during June, July and August the density becomes greatest in the high latitudes of the Southern Hemisphere.

Many areas with high windpower values experience midlatitude winter storms, trade winds or monsoons. In other cases, the shape of the land funnels the wind into reliable jets. Timothy Liu, a researcher at the Jet Propulsion Laboratory in Pasadena, California, who compiled the map with his colleagues (W. T. Liu et al. Geophys. Res. Lett. 35, L13808;
2008), says that the higher producing areas could offer 500-800 watts of energy per square metre. But even with perfect turbines, only $60 \%$ of that could be recovered. And given how far apart turbines need to be, realistic numbers would be much lower still.

Europe's wind power capacity is estimated to swell from $\mathbf{5 6 . 5}$ gigawatts now to up to 40 gigawatts offshore by 2020 . The United States is far behind, but projects in Delaware and Massachusetts are finally moving ahead. Emma Marris

\title{
Mouse miRNA library to open
}

Biologists working with 'knockout' mice that have been genetically engineered to inactivate certain genes are creating a library of knockouts of all microRNAs (miRNA) known in mice.

The collection, an initiative of the Sanger Institute in Cambridge, UK, is the first to tackle the nearly 500 miRNAs that scientists have identified in the mouse genome. The resource will eventually be available to all researchers studying the diverse systems affected by these shorts strands of nucleotides that regulate gene expression. Scientists speculate that mice may have more than a thousand miRNAs.

The Sanger project, named $\mu$ KOMP because it's a micro counterpart to KOMP, the Knockout Mouse Project for protein-coding genes run by the US National Institutes of Health, should help those who are making knockout mice. It will offer the genetic tools and, ultimately, embryonic stem-cell lines for knockout mice.

"This will actually cut out a part of the process," says Allan Bradley, director of the Sanger Institute. Making a knockout mouse can soak up a year or so of a researcher's time, and cost thousands of pounds with no guarantee of success.
"I wish they had it already," says Ying-Hui $\mathrm{Fu}$, a neuroscientist at the University of California, San Francisco, who wanted to knock out an miRNA gene for her work on circadian rhythms and multiple sclerosis. "More and more, people are realizing almost every biological pathway has miRNA involvement."

miRNAs regulate protein production in several biological systems and have been implicated in cancer and heart disease. In 2007, four labs simultaneously published reports of the first miRNA knockout mice ${ }^{1-4}$. Depending on the miRNA deleted, these mice develop immune deficiencies or holes in their hearts.

The Sanger team will make all the knockouts using one method, and in the same strain of mice, so scientists will be able to directly compare different mutations. "That is so important," Fu says. "Different strain backgrounds sometimes give you totally different results." Amber Dance

\footnotetext{
van Rooij, E. et al. Science 316, 575-579 (2007)

2. Thai, T.-H. et al. Science 316, 604-608 (2007).

3. Rodriguez, A. et al. Science 316, 608-611 (2007).

4. Zhao, Y. et al. Cell 129, 303-317 (2007).
} 